ISSN: $2338-4794$

Vol.6. No. 3 Sept.- Des. 2018

\title{
PENGARUH KESEHATAN DAN KESELAMATAN KERJA ( K3 ) DAN LINGKUNGAN KERJA TERHADAP PRODUKTIVITAS KERJA KARYAWAN PT RICKSTAR INDONESIA
}

\author{
Catur Hadi Prabowo ${ }^{1)}$ \\ 1) Mahasiswa Program Studi Manajemen FE UNKRIS \\ Widodo ${ }^{2)}$ \\ 2) Dosen Program Studi Manajemen FE UNKRIS \\ Alamat: Kampus UNKRIS, Jatiwaringin Jakarta Timur \\ Email: widodounkris@gmail.com.id
}

\begin{abstract}
Abstrcat: This research aims to analyze the influence of occupational health and safety and the work environment against work productivity of employees of PT (limited liability company) Rickstar Indonesia. The population used in this research were part of the production of PT (limited liability company) Rickstar Indonesia as many as 50 employees with sampling techniques using simple random sampling and data analysis techniques using analysis multiple linear regression. The results showed that there was influence of occupational health and safety and the work environment against work productivity of employees of PT (limited liability company) Rickstar Indonesia.
\end{abstract}

Keywords: Occupational health and safety (K3), work environment and work productivity

\section{PENDAHULUAN}

Dalam dunia bisnis sekarang ini sangat kompetitif khususnya perusahaan manufaktur dan sangat pesat perkembangannya. Persaingan dalam negeri khususnya maupun internasional menjadi motivasi tersendiri bagi semua jenis perusahaan manufaktur untuk senantiasa mengikuti perkembangan zaman yang terus berubah. Dalam mengikuti persaingan tersebut maka sangat perlu adanya inovasi, dan menjaga kualitas suatu produk yang dihasilkan untuk menjaga kepuasan pelanggan, dan menaikkan kesejahteraan para karyawannya, dengan demikian penting untuk perusahaan meningkatkan produktivitas salah satunya melalui pemberian program kesehatan dan keselamatan kerja (K3) dan lingkungan kerja yang kondusif untuk seluruh karyawan khususnya pada bagian produksi dengan harapan dapat memberikan stimulus dan memotivasi karyawan tersebut untuk bekerja dengan produktif. Penyesuaian kedua aspek agar dapat berjalan sesuai dengan yang diharapkan maka perusahaan perlu juga untuk mengimplementasikan displin ilmu manajemen sebagai upaya untuk meningkatkan produktivitas.

Manajemen adalah suatu proses perencanaan, pengorganisasian, kepemimpinan, dan pengendalian upaya dari anggota organisasi serta penggunaan semua sumber daya yang ada pada organisasi untuk mencapai tujuan organisasi yang telah ditetapkan sebelumnya. Disamping itu perusahaan juga membutuhkan sumber daya manusia untuk menjalankan segala bentuk sumber daya yang dimilikinya yaitu $5 \mathrm{M}$ (Man, Material, Methode, Machine, Money), dan salah satu sumber daya perusahaan yaitu sumber daya manusia. Sumber daya manusia adalah bagian perusahaan yang sangat penting, karena pada dasarnya manusia mempunyai peran yang strategis sebagai 
pelaksana dari fungsi manajemen yaitu perencanaan, pengorganisasian, pengolahan, pengendalian demi mencapai tujuan yang sudah ditetapkan. Oleh sebab itu perlu diketahui bahwa untuk meningkatkan produktivitas karyawan diperlukan implementasi ilmu manajamen sumber daya manusia. Dengan segala upaya yang sudah direncanakan perusahaan memerlukan komponen untuk menunjang produktivitas yang salah satunya adalah kesehatan dan keselamatan kerja (K3) untuk menunjang produktivitas, kesehatan kerja adalah suatu usaha dan keadaan yang memungkinkan seseorang mempertahankan kondisi kesehatannya dalam pekerjaan.

Keselamatan kerja adalah suatu keadaan dalam lingkungan/tempat kerja yang dapat menjamin secara maksimal keselamatan orang-orang yang berada didaerah/tempat tersebut baik orang tersebut karyawan/bukan karyawan dari organisasi kerja itu. Kesehatan dan keselamatan kerja (K3) karyawan berguna untuk menekan risiko terjadinya kecelakaan saat bekerja dengan memberikan pakaian kerja yang sesuai terutama bagian produksi, karena pada bagian tersebut terdapat alat yang memungkinkan terjadinya kecelakaan kerja itu dapat dibilang sangat tinggi, serta para supervisor turut mengawasi para karyawan yang mengindahkan ketentuan sendiri dengan tidak memakai sarung tangan, masker, sepatu, pakaian, dan helm yang sesuai standart yang sudah ditetapkan. Program tersebut juga menjadi upaya pencegahan dari timbulnya penyakit, hal ini karena notabene perusahaan manufaktur pasti membutuhkan bahan kimia untuk menghasilkan suatu produk. Untuk itu jika perusahaan tidak memerhatikan dengan baik segala bentuk kesehatan dan keselamatan kerja (K3) karayawan akan berdampak buruk di masa yang akan datang karyawan itu sendiri seperti terjadinya amputasi anggota tubuh, penyakit pernafasan, dan penyakit kulit. Selain itu perusahaan juga harus memerhatikan lingkungan kerja yang nyaman dan memberikan rasa aman bagi karyawan, sehingga diharapkan mampu memberikan stimulus yang baik untuk karyawan memberikan konstribusi optimal atau dengan kata lain mencapai produkivitas tinggi.

Produktivitas kerja karyawan merupakan faktor yang sangat penting dalam menunjang keberhasilan atau menguntungkan bagi pengusaha maupun bagi karyawan terutama untuk kesejahteraannya. Produktivitas juga mencerminkan etos kerja karyawan yang terlibat dalam perusahaan untuk memberikan konstribusi optimal. Objek yang akan dibahas terkait produktivitas kerja karyawan PT (Perseroan Terbatas) Rickstar Indonesia merupakan salah satu perusahaan yang bergerak di bidang pembuatan panel elektrikal, perusahaan tersebut megalami penurunan produksi dari bulan januari - april tahun 2018 hal itu disebabkan karena karyawan belum cukup memiliki perlengkapan pelindung tubuh sebagai penunjang untuk menghasilkan suatu produk dalam hal ini panel elektrikal, berikut data yang didapat dalam penelitian ini: 


\section{Tabel 1. Hasil Produksi Kuartal I Tahun 2018 PT ( Perseroan Terbatas ) Rickstar Indonesia}

\begin{tabular}{lccc} 
Kuartal I & Karyawan & Produksi/Bulan & Target/Bulan \\
\hline Januari & 50 & 60 & 70 \\
Februari & 50 & 54 & 70 \\
Maret & 50 & 48 & 70 \\
April & 50 & 47 & 70 \\
\hline
\end{tabular}

Sumber: PT ( Perseroan Terbatas ) Rickstar Indonesia

Berdasarkan Tabel 1, merupakan data yang membuktikan penurunan produktivitas selama kuartal pertama di tahun 2018. Menurut pengamatan sementara yang telah dilakukan observasi langsung ke objek penelitian yaitu karena kurangnya perhatian perusahaan terkait penerapan program kesehatan dan keselamatan kerja ( K3 ) dan lingkungan kerja yang dapat menunjang produktivitas kerja karyawan.

\section{LANDASAN TEORI}

\section{Produktivitas Kerja}

Menurut Wibowo

(2010)

mengungkapkan bahwa secara konseptual "produktivitas kerja dapat diartikan sebagai hubungan antar keluaran atau hasil organisasi dengan masukkan yang diperlukan". Menurut Soeprihanto (2007) produktivitas kerja adalah "perbandingan antara hasil - hasil yang dicapai dengan keseluruhan sumber daya yang digunakan atau perbandingan jumlah produksi (output) dengan sumber daya yang digunakan (input)". Sedangkan menurut Sunyoto (2012) produktivitas kerja "adalah ukuran yang menunjukkan pertimbangan antara output yang dikeluarkan perusahaan serta peran tenaga kerja yang dimiliki per satuan waktu".

Dari beberapa pengertian menurut para ahli maka dapat disimpulkan bahwa produktivitas merupakan perbandingan antara hasil produksi yang dicapai oleh karyawan dengan keseluruhan sumber daya yang digunakan perusahaan untuk melaksanakan kegiatan produksi dalam satuan waktu tertentu.

Pengukuran produktivitas kerja menurut Sutrisno (2009), mengemukakan "rumusan umum dari produktivitas kerja mengandung pengertian perbandingan antara hasil yang dicapai (output) dengan keseluruhan sumber daya yang digunakan (input)". Mengingat sumber daya manusia atau tenaga kerja merupakan faktor penggerak dari faktor-faktor lainnya, maka suatu organisasi atau perusahaan sangat penting untuk melakukan pengukuranpengukuran produktivitas kerja karyawannya. Pengukuran mengenai produktivitas kerja pada umumnya bersifat kuantitatif. Produktivitas kerja berkaitan dengan efisiensi penggunaan dalam memperoleh output. Dengan demikian produktivitas kerja merupakan kombinasi efektivitas output dan efisiensi input.

Untuk mengukur produktivitas kerja diperlukan suatu indikator menurut Sutrisno (2009) adalah: a). Kemampuan; Kemampuan seseorang sangat bergantung pada keterampilan yang dimilikinya serta profesionalisme dalam bekerja sehingga dengan adanya kemampuan diharapkan dapat mencapai target yang sudah ditetapkan. b). Meningkatkan hasil yang dicapai; Berusaha meningkatkan hasil yang dicapai dengan memanfaatkan produktivitas masing-masing sumber daya yang terlibat 
dalam suatu pekerjaan. c). Semangat kerja; Dapat dilihat dari etos kerja yang dicapai satu hari, kemudian dibandingkan dengan hari sebelumnya. d). Pengembangan diri; Mengembangkan diri untuk meningkatkan kemampuan kerja. Pengembangan diri dapat dilakukan dengan melihat tantangan dan harapan dengan apa yang akan dihadapi. e). Mutu; Selalu berusaha meningkatkan mutu lebih baik dari yang lalu. Mutu merupakan hasil pekerjaan yang dapat menunjukkan kualitas kerja karyawan. f). Efisiensi; Perbandingan antara hasil yang dicapai dengan keseluruhan sumber daya yang digunakan. Masukkan dan keluaran merupakan aspek produktivitas yang memberikan pengaruh yang cukup signifikan.

\section{Kesehatan dan Keselamatan Kerja (K3)}

Menurut Ardana (2012) keselamatan dan kesehatan kerja (K3) adalah "upaya perlindungan yang ditujukan agar tenaga kerja dan orang lain di tempat kerja atau selalu dalam keadaan selamat dan sehat sehingga setiap sumber produksi dapat digunakan secara aman dan efisien". Occupational Health Safety Asessment Series merupakan standar internasional untuk penerapan sistem manajemen keselamatan dan kesehatan kerja, (OHSAS 18001:2007) mendefinisikan "keselamatan dan kesehatan kerja sebagai kondisi dan faktor yang mempengaruhi keselamatan dan kesehatan kerja serta orang lain yang berada di tempat kerja". Menurut Mangkunegara (2011) berpendapat bahwa program "kesehatan kerja menunjukkan pada kondisi yang bebas dari gangguan fisik, mental, emosi atau rasa sakit yang disebabkan oleh lingkungan kerja". Risiko kesehatan merupakan faktor-faktor dalam lingkungan kerja yang bekerja melebihi periode waktu yang ditentukan, lingkungan yang dapat membuat stress emosi atau gangguan fisik. Menurut UU No.23 Tahun 1992 (dalam
Konradus, 2012) kesehatan dan keselamatan kerja merupakan "salah satu pilar untuk meningkatkan kualitas sumber daya manusia, terutama meningkatkan derajat kesehatan pekerja yang optimal dan usia harapan hidup yang lebih lama, sehingga dapat meningkatkan produktivitas kerja". Dari beberapa pengertian tersebut dapat ditarik kesimpulan bahwa kesehatan dan keselamatan kerja merupakan suatu kondisi seseorang akan bekerja dengan optimal jika diberikan stimulus yang baik yaitu terjaganya keamanan dan kesehatan karyawan serta tidak memikirkan bahwa dirinya bisa terkena penyakit jika bekerja ditempat tersebut.

Alat perlindungan diri menurut (PER.08/MEN/VII/2010, Pasal 3):

a. Pelindung kepala, digunakan untuk meredam benturan

b. Pelindung mata dan muka, digunakan untuk melindungi mata dari benda asing dan melindungi dari percikan api atau asap

c. Pelindung telinga, digunakan untuk meredam suara bising yang dihasilkan oleh mesin

d. Pelindung pernapasan, digunakan untuk menyaring udara yang masuk melalui hidung sehingga tidak mengurangi kualitas udara yang masuk ke tubuh

e. Pelindung tangan dan/atau, digunakan untuk melindungi tangan dari berbagai bentuk cairan kimia jika menempel di tangan akan terasa gatal

f. Pelindung kaki, digunakan untuk melindungi kaki jika tertimpa beban atau material yang berat.

Tahapan dalam penyusunan Sistem Manajemen K3 menurut OHSAS 18001:

a. Melakukan indentifikasi risiko secara dini dan bahaya yang akan terjadi di lingkungan kerja 
b. Menyesuaikan dan melaksanakan ketetapan undang - undang dan peraturan hukum yang berlaku

c. Menetapkan sebuah target perusahaan sesuai dengan standart operational procedure ( SOP )

d. Semua komponen dalam perusahaan melaksanakan program perencanaan demi tercapainya target dan objek yang telah ditentukan oleh perusahaan

e. Mengharuskan adanya perencanaan terhadap kejadian darurat dalam kegiatan operasional

f. Jangan lupa untuk melakukan review terhadap target dan para pelaksana sistem

g. Penetapan kebijakan sebagai usaha untuk mencapai kemajuan yang berkesinambungan.

Keuntungan dari Tempat Kerja yang Aman dan Sehat

Menurut.Jackson (2011) keuntungan tersebut ialah: a). Produktivitas akan meningkat karena berkurangnya hari kerja yang hilang. b).Meningkatkan efisiensi dan kualitas tenaga kerja yang lebih sehat. c). Berkurangnya biaya pengeluaran medis dan asuransi. d). Menurunnya tingkat pembayaran karyawan karena sedikitnya tuntutan yang diajukan. e). Meningkatnya reputasi sebagai perusahaan terbaik.

Indikator Program Keselamatan dan Kesehatan Kerja (K3) 'Menurut Suma'mur (2013), adalah : a). Alat - alat perlindung kerja, seperangkat yang digunakan untuk melindungi tubuh dan meminimalisir penyakit akibat kerja. b). Ruang kerja yang aman, ruang yang kerja yang memiliki jarak antara karyawan dengan mesin c). Penggunaan peralatan kerja, seperangkat yang digunakan untuk mepermudah pekerjaan dan menghindari dari risiko terkena mesin. d). Ruang kerja yang sehat, ruang kerja memiliki ventilasi cukup atau terjaganya kualitas udara pada area kerja. e). Penerangan diruang kerja, ruang kerja yang memiliki penerangan guna mempermudah pekerjaan baik pagi, siang, dan malam.

\section{Lingkungan Kerja}

Menurut Sedarmayanti (2009) lingkungan kerja adalah "keseluruhan alat perkakas dan bahan yang dihadapi, lingkungan sekitarnya dimana seseorang bekerja, metode kerja, dan pengaturan kerja baik sebagai perseorangan maupun sebagai kelompok". Menurut Prawirosentono (2007) menyatakan bahwa "lingkungan kerja merupakan suasana dan keadaaan lingkungan kerja banyak memengaruhi keselamatan dan kesehatan kerja". Untuk menciptakan keselamatan kerja diperlukan penerangan lampu yang memadai, sirkulasi udara yang menjamin kesegaran kerja dan lantai menjamin orang tidak mudah terpeleset karena licin.

Sedangkan kesehatan kerja tergantung pada lingkungan yang mendukung para tenaga kerja terjamin kesehatannya, misalnya sirkulasi udara yang baik. Menurut Sunyoto (2012) lingkungan kerja "adalah segala sesuatu yang ada disekitar para pekerja dan yang dapat memengaruhi dirinya dalam menjalankan tugas-tugas yang dibebankan, misalnya musik, kebersihan, penerangan dan lain-lain". Dari beberapa pendapat yang dikemukakan oleh para ahli maka dapat disimpulkan bahwa lingkungan kerja merupakan upaya yang diberikan perusahaan kepada karyawan seperti penerangan lampu yang memadai, sirkulasi udara yang menjamin kesegaran kerja, dan kebersihan tempat kerja agar dapat bekerja dengan optimal.

Menurut Serdamayati (2009) faktorfaktor yang memengaruhi lingkungan kerja fisik, yaitu: a). Kebersihan; Setiap organisasi termasuk juga instansi pemerintahan selalu menjaga kebersihan lingkungan kerja. Hal ini karena kebersihan sangat berpengaruh bagi kesehatan karyawan, dengan demikian 
produktivitas kerja karyawan secara otomatis akan meningkatkan. Hal ini di karena perasaan nyaman pada tempat yang tepat dalam yaitu keadaan tempat yang bersih, sehingga karyawan dapat memaksimalkan pekerjaannya. b) Pemilihan Warna; Pemilihan warna dalam ruangan tempat kerja akan membawa pengaruh pada kondisi kerja karyawan. Karena warna akan membawa efek psikologis bagi karyawan disamping memiliki keterkaitan dengan penerangan dalam ruang kerja pada umunya belum banyak mendapatkan perhatian dari organisasi. c). Tingkat Pencahayaaan; Pencahayaan diruang kerja merupakan faktor yang sangat penting untuk meningkatkan produktivitas kerja karyawan. Melalui pencahayaan yang baik dan mencukupi syarat akan mendorong karyawan dapat bekerja dengan baik, teliti dalam bekerja, dan terjaganya kualitas kerja yang baik. Pencahayaan yang baik adalah cukupnya sinar yang masuk kedalam ruangan kerja karyawan dan pencahayaan yang baik tidak hanya dari lampu melainkan juga berasal dari sinar matahari. d). Suara; Suara adalah tingkat kebisingan yang dapat mengganggu pekerjaan karyawan. Secara langsung suara yang bising akan berpengaruh terhadap kondisi fisik karyawan dan akhirnya secara tidak langsung akan menurunkan prestasi kerja karyawan. Oleh karena itu suara juga harus diperhatikan oleh manajemen dalam menciptakan lingkungan kerja yang baik. Dengan demikian pengadaan alat peredam suara (earplug) sangat dibutuhkan untuk mencegah terjadinya penyakit pendengaran yang dialami karyawan. e). Udara dan suhu; Udara yang bersih mempunyai pengaruh positif dalam meningkatkan produktivitas kerja karyawan, kualitas kerja, kesehatan serta semangat kerja. Kualitas udara yang terdapat pada lingkungan kerja akan menurun apabila terjadi pencemaraan udara yang disebabkan oleh asap rokok, debu, dan asap mesin. Suhu merupakan faktor yang penting karena dapat memengaruhi kenyamanan karyawan, sehingga besar kemungkinannya jika kualitas udara rendah maka akan menurunkan produktivitas kerja karyawan".

Indikator lingkungan kerja menurut Sedarmayanti (2009) ada beberapa indikator lingkungan kerja, yaitu: 1). Lingkungan Kerja Fisik: a). Penerangan; Bekerja pada ruangan yang gelap akan menyebabkan ketegangan pada mata, intensitas cahaya yang tepat dapat membantu karyawan dalam memperlancar aktivitas kerjanya. b). Suhu Udara; Suhu udara adalah suatu variabel dimana terdapat perbedaan individual yang besar. Dengan demikian untuk memaksimalkan produktivitas kerja penting bahwa karyawan bekerja di suatu lingkungan dimana suhu diatur dengan baik sehingga karyawan mampu bekerja dengan optimal. c). Suara Bising; Bukti dari telaah telaah tentang suara menunjukkan bahwa suara - suara yang konstan atau dapat diramalkan memberikan pengaruh negatif dan mengganggu konsentrasi karyawan. d). Ruang Gerak; Ruang gerak sangat memengaruhi produktivitas kerja karyawan, ruang gerak yang sempit membuat karyawan sulit bergerak sehingga menghasilkan prestasi kerja yang lebih rendah jika dibandingkan dengan karyawan yang memiliki ruang kerja yang luas. 2). Lingkungan Kerja Non Fisik: a). Hubungan Kerja Antar Karyawan dengan Pimpinan; Sikap atasan terhadap bawahan memberikan pengaruh bagi karyawan dalam melaksanakan aktivitasnya, sikap atasan yang bersahabat yaitu saling menghormati dan menghargai antara karyawan dengan pimpinan untuk kerjasama dalam mencapai tujuan perusahaan. Sikap bersahabat yang diciptakan akan menimbulkan semangat kerja untuk karyawan. b). Hubungan Antar Karyawan; Hubungan kerja antar karyawan sangat diperlukan untuk melakukan 
pekerjaan, terutama bagi karyawan yang bekerja secara kelompok. Apabila terjadi konflik maka akan memperkeruh suasana dalam bekerja sehingga dapat menurunkan semangat kerja karayawan. Hubungan yang terjalin dengan baik antara karyawan yang satu dengan yang lain maka akan meningkatkan semangat kerja untuk karyawan itu sendiri, dimana mereka saling kerjasama atau membantu dalam menyelesaikan suatu pekerjaan.

\section{METODE PENELITIAN}

Metode penelitian yang digunakan adalah dengan pendekatan explanatory Analysis yaitu menjelaskan hubungan kausalistik antar variabel.

Populasi yang digunakan pada penelitian ini adalah karyawan bagian produksi PT (Perseroan Terbatas) Rickstar Indonesia. Dengan metode pengambilan sampel dalam penelitian ini dilakukan dengan teknik sampling jenuh. Pada penelitian ini sampel yang akan diambil berjumlah 50 responden karena populasi pada bagian produksi PT (Perseroan Terbatas) Rickstar Indonesia relatif sedikit.

Teknik analisis data yang digunakan dengan regresi dan korelasi baik secara sederhana maupun berganda, dilanjutkan dengan uji hipoteis

\section{HASIL PENELITIAN}

\section{Pengaruh Kesehatan dan Keselamatan Kerja (K3) dan Lingkungan Kerja Terhadap Produktivitas Kerja Karyawan PT (Perseroan Terbatas) Rickstar Indonesia di Cakung Jakarta Timur}

Hasil perhitungan membuktikan bahwa terdapat sinergi antara variabel kesehatan dan keselamatan kerja (K3) dan lingkungan kerja secara simultan memberikan konstribusi terhadap produktivitas kerja karyawan PT (Perseroan Terbatas) Rickstar Indonesia di Cakung Jakarta Timur.

Koefisien determinasi $\left(\mathrm{R}^{2}\right)$ sebesar 0,887 artinya bahwa kesehatan dan keselamatan kerja (K3) dan lingkungan kerja memberikan konstribusi sebesar 88,7\% terhadap produktivitas kerja karyawan PT (Perseroan Terbatas) Rickstar Indonesia di Cakung Jakarta Timur, sedangkan konstribusi sisanya yaitu $11,3 \%$ terjadi pada faktor lain yang dalam penelitian ini tidak dibahas berjumlah 50 responden karena populasi pada bagian produksi PT (Perseroan Terbatas) Rickstar Indonesia relative sedikit.

Teknik analisa data yang digunakan dengan regresi baik secara sederhana maupun berganda, dilanjutkan dengan uji hipotesi

Model Prediksi: $Y=1,690+1,661+0,142$

Kesehatan dan keselamatan kerja dan lingkungan kerja berpengaruh positif dan signifikan terhadap produktivitas kerja karyawan PT (Perseroan Terbatas) Rickstar Indonesia di Cakung Jakarta Timur, pada tingkat kepercayaan 95\%. Koefisien kesehatan dan keselamatan kerja (K3) 1,661 artinya jika ada peningkatan kesehatan dan keselamatan kerja satu kali, maka produktivitas kerja meningkat 1,661 kali. Koefisien lingkungan kerja sebesar 0,142, artinya jika ada peningkatan lingkungan kerja sebesar satu kali, maka lingkungan kerja akan meningkat 0,142 kali.

F hitung sebesar 185,092 jika dibandingkan dengan $\mathrm{F}_{\text {tabel }}$ sebesar 185.092 yang didapat dari ( $\mathrm{DK}=\mathrm{n}-\mathrm{k}-1 ;=50-2$ $1=47$ ), maka $F_{\text {hitung }}$ lebih besar dari $F_{\text {tabel }}$ $(185.092>3,20)$, artinya secara bersama sama kesehatan dan keselamatan kerja (K3) dan lingkungan kerja berpengaruh signifikan pada tingkat kepercayaan $95 \%(0,05)$ atau dengan F signifikan yaitu sebesar 0,000 < 
0,05. Dengan demikian maka $\mathrm{P}_{\text {sign }}<0,05$ maka $\mathrm{H}_{0}$ ditolak, $\mathrm{Ha}$ diterima, artinya variabel - variabel independen yang dimasukkan dalam model mempunyai pengaruh secara simultan terhadap variabel dependen.

\section{Pengaruh Kesehatan dan Keselamatan Kerja (K3) Terhadap Produktivitas Kerja Karyawan PT (Perseroan Terbatas) Rickstar Indonesia di Cakung Jakarta Timur}

Untuk mengetahui apakah kesehatan dan keselamatan kerja (K3) memengaruhi tinggi atau rendahnya produktivitas kerja karyawan PT (Perseroan Terbatas) Rickstar Indonesia di Cakung Jakarta Timur.

Nilai $\mathrm{R}^{2}$ sebesar 0,886 artinya kesehatan dan keselamatan kerja memberikan konstribusi sebesar $88,6 \%$ terhadap produktivitas kerja karyawan dan sisanya sebesar $11,4 \%$ dibagi kepada faktor lain.

Model Prediksi Y=1.227 + $1.619\left(\mathrm{X}_{1}\right)$

kesehatan dan keselamatan kerja berpengaruh positif dan signifikan pada tingakat kepercayaan $95 \%$ terhadap produktivitas kerja karyawan PT (Perseroan Terbatas) Rickstar Indonesia di Cakung Jakarta Timur. Koefisien kesehatan dan keselamatan kerja (K3) sebesar 1,619, artinya jika ada peningkatan sebesar 1,619 kali, maka kesehatan dan keselamatan kerja (K3) akan meningkat sebesar 1,619 atau sebaliknya. Konstanta sebesar 1,227 yang berarti bahwa ada atau tidak ada kesehatan dan keselamatan kera (K3) di PT (Perseroan Terbatas) Rickstar Indonesia di Cakung Jakarta Timur sudah terbentuk 1,227. Dan untuk menguji hubungan secara parsial variabel kesehatan dan keselamatan kerja (K3) terhadap produktivitas kerja karyawan signifikan atau tidak, dilakukan dengan

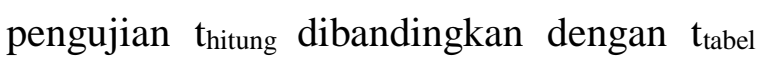
dengan tingkat $\alpha=0,05$ berdasarkan data yang telah diolah menghasilkan nilai thitung $_{=}$ 19,295 dan nilai tabel yang didapat dari (derajat kebebasan $=\mathrm{n}-\mathrm{k} ;(50-2)$ dengan uji 2 pihak yaitu $=1,299$, sehingga dapat disimpulkan bahwa $\mathrm{t}_{\text {sign }}<0,05$ maka $\mathrm{H}_{0}$ ditolak, $\mathrm{H}_{\mathrm{a}}$ diterima, artinya variabel independent merupakan penjelas yang signifikan terhadap variabel dependent atau terdapat pengaruh signifikan antara variabel kesehatan dan keselamatan kerja (K3) terhadap produktivitas kerja karyawan PT (Perseroan terbatas) Rickstar Indonesia di Cakung Jakarta Timur.

\section{Pengaruh Lingkungan Kerja Terhadap Produktivitas Kerja Karyawan PT (Perseroan Terbatas) Rickstar Indonesia di Cakung Jakarta Timur}

Koefisien determinasi $\left(\mathrm{R}^{2}\right)$ sebesar 0,212 , yang berarti bahwa lingkungan kerja memberikan konstribusi $21,2 \%$ terhadap produktivitas kerja karyawan PT (Perseroan Terbatas) Rickstar Indonesia

$$
\text { Model Prediksi Y= 29,790+0.416 }\left(\mathrm{X}_{2}\right)
$$

Lingkungan kerja berpengaruh positif dan signifikan pada tingkat kepercayaan 95\% terhadap produktivitas kerja karyawan PT (Perseroan Terbatas) Rickstar Indonesia di Cakung Jakarta Timur. Koefisien determinasi lingkungan kerja sebesar 0,416, artinya jika ada peningkatan sebesar 0,416 kali, maka lingkungan kerja akan meningkat sebesar 0,416 atau sebaliknya. Konstanta sebesar 29,790 yang berarti bahwa ada atau tidak ada lingkungan kerja di PT (Perseroan Terbatas) Rickstar Indonesia di Cakung Jakarta Timur sudah terbentuk 29,790. Dan untuk menguji hubungan secara parsial variabel lingkungan kerja terhadap produktivitas kerja karyawan signifikan atau 
tidak, dilakukan dengan pengujian $t_{\text {hitung }}$ dibandingkan dengan $t_{\text {tabel }}$ dengan tingkat $\alpha=$ 0,05 berdasarkan data yang telah diolah menghasilkan nilai $t_{\text {hitung }}=3,597$ dan nilai $\mathrm{t}_{\text {tabel }}$ yang didapat dari ( derajat kebebasan = n - k; $\quad(50$ - 2) dengan uji 2 pihak yaitu 1,299, sehingga dapat disimpulkan $t_{\text {sign }}<$ 0,05 maka $\mathrm{H}_{0}$ ditolak, $\mathrm{H}_{\mathrm{a}}$ diterima, artinya variabel independent merupakan penjelas yang signifikan terhadap variabel dependent atau terdapat pengaruh signifikan antara variabel kesehatan dan keselamatan kerja (K3) terhadap produktivitas kerja karyawan PT (Perseroan terbatas) Rickstar Indonesia di Cakung Jakarta Timur.

\section{PEMBAHASAN}

Dari hasil penelitian menunjukkan bahwa: 1). Pengaruh kesehatan dan keselamatan kerja karyawan (K3) terhadap prduktivitas kerja karyawan dilakukan uji secara parsial diperoleh hasil uji $t_{\text {hitung }}$ sebesar 19,295 > $t_{\text {tabel }} 1,299$ dan nilai signifikansi sebesar $0,000<0,005$. Berdasarkan hasil tersebut dapat dikatakan bahwa hipotesis pertama (H1) diterima, kesehatan dan keselamatan kerja karyawan (K3) berpengaruh positif dan signifikan terhadap variabel produktivitas kerja karyawan PT (Perseroan Terbatas) Rickstar Indonesia di Cakung Jakarta Timur. 2). Pengaruh lingkungan kerja terhadap produktivitas kerja karyawan; Pengaruh lingkungan kerja terhadap prduktivitas kerja karyawan dilakukan uji secara parsial diperoleh hasil uji $t_{\text {hitung }}$ sebesar 3,597 $>t_{\text {tabel }}$ 1,299 dan nilai signifikansi sebesar 0,001 < 0,005. Berdasarkan hasil tersebut dapat dikatakan bahwa hipotesis kedua (H2) diterima, lingkungan kerja berpengaruh positif dan signifikan terhadap variabel produktivitas kerja karyawan PT (Perseroan Terbatas) Rickstar Indonesia di Cakung Jakarta Timur. 3). Pengaruh kesehatan dan keselamatan kerja karyawan (K3) dan lingkungan kerja terhadap produktivitas kerja karyawa PT (Perseroan Terbatas) Rickstar Indonesia di Cakung Jakarta Timur. Berdasarkan hasil penelitian yang telah dilakukan dengan menguji dua variabel dan satu variabel terikat secara bersama - sama atau simultan menunjukkan bahwa nilai Fhitung sebesar 185,092 > $\mathrm{F}_{\text {tabel }}$ 3,20 dan $\mathrm{P}_{\text {sign }}$ yaitu $0,000<0,05$ maka $\mathrm{H}_{0}$ ditolak, Ha diterima, artinya hipotesis ketiga (H3) dengan cara menguji variabel - variabel independent yang dimasukkan ke dalam model mempunyai pengaruh secara simultan terhadap variabel dependent.

\section{KESIMPULAN DAN SARAN}

\section{Kesimpulan}

Berdasarkan hasil olah data menggunakan metode analisis regresi berganda yang dilakukan dalam penilitian ini maka dapat ditarik kesimpulan bahwa: 1). Secara simultan kesehatan dan keselamatan kerja (K3) dan lingkungan keja berparuh positif terhadap produktivitas kerja karyawan PT (Perseroan Terbatas) Rickstar Indonesia di Cakung Jakarta Timur. 2). Secara parsial kesehatan dan keselamatan kerja (K3) berpengaruh positif terhadap produktivitas kerja karyawan PT (Perseroan Terbatas) Rickstar Indonesia di Cakung Jakarta Timur. 3). Secara parsial lingkungan kerja berpengaruh positif terhadap produktivitas kerja karyawan PT (Perseroan Terbatas) Rickstar Indonesia di Cakung Jakarta Timur.

\section{Saran}

Setelah dilakukan berbagai pengujian data terkait pengaruh kesehatan dan keselamatan kerja (K3) dan lingkungan kerja terhadap produktivitas kerja karyawan dan telah ditarik kesimpulan, maka selanjutnya penulis mencoba untuk memberikan saran yang mungkin dapat ditindak lanjuti, diantaranya: 1). Untuk 
faktor kesehatan dan keselamatan kerja karyawan pada bagian produksi dapat memerhatikan tingkat risiko yang akan diterima karyawan jika tidak dilengkapi dengan alat pelindung diri yang sesuai dengan undang - undang yang berlaku terutama pelingung kepala, tangan, dan kaki. Selanjutnya rutin melakukan pengawasan terhadap karyawan yang selalu mengindahkan ketentuan sendiri dan dapat mengancam kesehatan dan keselamatannya. 2). Untuk faktor lingkungan kerja pada bagian produksi untuk memberikan penerangan yang cukup diarea produksi dan sirkulasi udara yang baik serta penataan mesin yang tepat agar karyawan dapat bekerja dengan baik. Kedua selalu menjaga komunikasi antar sesama karyawan dan atasan agar terjalin keharmonisan sehingga dapat berkonstribusi optimal.

\section{DAFTAR PUSTAKA}

John Suprihanto. 2014. Manajemen, Penerbit Universitas Gadjah Mada.

Danang Sunyoto. 2012. Manajemen Sumber Daya Manusia, Jakarta, Penerbit PT Buku Seru.

Edy Sutrisno. 2010. Manajemen Sumber Daya Manusia, Jakarta, Penerbit Kencana.

Sugiyono. 2016. Metodologi Penelitian Kuantitatif, Kualitatif, dan R\&D, Bandung, Penerbit CV Alfabeta.

Sedarmayanti. 2009. Sumber Daya Manusia dan Produktivitas Kerja, Bandung, Penerbit Maju Mundur.
I Komang Ardana. 2012. Manajemen Sumber Daya Manusia, Yogyakarta, Penerbit Graha Ilmu.

Mangkunegara. 2011. Manajemen Sumber daya Manusia. Perusahaan. Bandung, Penerbit Remaja Rosda.

Suma'mur 2013. Higiene Perusahaan dan Kesehatan Kerja, Jakarta, Penerbit Sagung Seto.

Prawirosentono. 2007. Filosofi Baru Tentang Manajemen Mutu Terpadu Abad 21: Kiat Membangun Bisnis Kompetitif, Jakarta, Penerbit Bumi Aksara.

Sugiyono 2016. Metode Penelitian Kualitatif Kuantitatif dan Kombinasi ( Mixed Methods ), Bandung, Penerbit PT Alfabeta.

Wibowo. 2010. Manajemen, Jakarta, Penerbit Rajawali Pers.

Arikunto. 2010. Prosedur Penelitian Suatu Pendekatan Praktik, Jakarta, Penerbit Rineka Cipta.

Imam Ghozali. 2013. Aplikasi Analisis Multivariate dengan Program SPSS, Semarang, Badan Penerbit Universitas Diponegoro.

Muhammad Nisfianoor. 2014. Pendekatan Statistika Modern Untuk Ilmu Sosial, Jakarta, Penerbit Salemba Humanika.

Juliansyah Noor. 2014. Analisis Data Penelitian Ekonomi \& Manajemen, Jakarta. Penerbit PT Gramedia.

Standart penerapan OHSAS 18001, https://strategibisnisdanisoseries.word press.com. 
